\title{
Towards a Liberation Theology of Indigenous Minority Language Groups: A Case Study on the Welsh Language
}

\section{Introduction}

During the Rugby World Cup in the autumn of 2015, just before the semi-final matches, referee Nigel Owens retweeted a comment in support of the use of the Welsh language. The original tweet was written as part of an annual day that celebrates and promotes the use of the Welsh language in Wales, known as Shwmae Sumae. His retweet was written in Welsh. Owens was then questioned by another Twitter user about whether he should be tweeting at all, but especially in Welsh, because it compromised the 'independence' of someone who should be 'neutral' during a Rugby tournament. This bias was expressed by Owens, his critics said, because he was only communicating to a Welsh audience and therefore excluding English speakers who could not understand it (see Owens, 2015). The assumption here is, of course, that English is a 'neutral' space and other languages are not. In response Owens said, 'You better tell all the other tweeters who tweet in their native tongue to stop tweeting then' (Owens, 2015). As someone who has always either lived or worked among communities where languages other than English are used as the preferred and natural method of communication (British Sign Language users and Welsh speakers), I find it difficult to comprehend the surprise that many English speakers seem to feel that others who live in the UK would prefer to use their own first language, indigenous to these islands, rather than the dominant language of the English majority. Sometimes, however, the hostility towards the Welsh language is expressed in more than mere surprise.

A friend recently asked, on Facebook, for publicity information, for a society of which they were a member, to be made available in Welsh. His first language is Welsh and the society was based in Wales, indeed in a part of Wales that is majority Welsh speaking. His question to the organizers was as simple as 'can this information be made available in Welsh'? The responses he received to this seemingly innocuous request are revealing, not just of incredulity that someone would want to use Welsh, but of attitudes that saw any requests for Welsh to be used as deeply problematic. To my mind, they reflected attitudes of deep-rooted prejudice and practices of marginalization and discrimination that would not be tolerated in many other contexts and circumstances. The responses were as follows:

- He was accused of being 'small-minded'

- He was accused of suggesting that English speaking Welsh people were not as Welsh as him

- He was accused of 'hating the English'

- His request was described as 'despicable and disgusting'

- Another said, 'why does he have to bitch?'

- One response said everything was in English so it was inclusive of everyone

- Another said his concerns were 'petty'

- He was told 'if you don't like it, don't come'

- And finally, and perhaps most ironic of all, he was told accusingly, 'diversity is the essence of a good life. Dogma and fundamentalism kills the soul. ${ }^{1}$

The last point is ironic, of course, because an appreciation of diversity is really all this person was asking for. No-one responded in support; all alternative voices were silenced by the ferocity of the attack on this individual.

The aggression in some of the responses above was quite shocking, but this kind of hostility is experienced by first language Welsh speakers on a daily basis ${ }^{2}$. My friend was asking for his identity, culture and language to be accepted as being of equal value and worth to his English counterparts

${ }^{1}$ The name of the individual, the society and the event are omitted to protect the identity of the person who shared this experience with me.

${ }^{2} \mathrm{~A}$ regular look at social media such as Twitter provides extensive evidence of this kind of hostility. 
and his experience resonated strongly with members of the Deaf community among whom I conducted research several years ago (Morris, 2008). In the fieldwork I conducted with the Deaf community, many would often explain how exhausting and soul-destroying the daily fight can be to be accepted as Deaf people who understand and live in the world differently to hearing people, and express that through a distinctive language and culture. Many Deaf British Sign Language (BSL) users reported to me that they would rather stay at home alone, or just mix with other Deaf people, than keep asking for access to society through their own language, only to be faced with aggression from the linguistic majority who could not understand why Deaf people would not want or be able to use English. The same is true for many Welsh speakers. They live with an attack on their identity, language and culture daily.

It is my contention that the marginalized and oppressed status of indigenous minority language groups in Europe in general (of which there are many) and in Britain in particular, as an area of identity politics and also as a question of equality and human rights, has been under-researched and given very little attention in theological and religious discourses. I posit that many indigenous minority language groups experience discrimination on a daily basis and this paper focuses in particular on the status of Welsh speakers in the United Kingdom while drawing on my earlier work with Deaf and disabled people to understand this marginalized status. The argument that follows subsequently aims to encourage further investigation into Welsh experiences of discrimination, and to invite theologians and scholars of religion to reflect on the contributions our disciplines could make to thinking about the status of indigenous minority language groups in Europe more generally ${ }^{3}$. As a contribution to that end, as someone inspired by liberation theologies, in conclusion, I begin to outline what the contours of a liberation theology of the Welsh language might look like.

\section{Agendas of Normalization: A Lens for Understanding Marginalization}

I have indicated that discrimination against indigenous minority language groups is a matter of identity politics and equality and human rights. I focus here especially on the experience of Welsh speakers, conscious that the contexts of each indigenous minority language group will be not be exactly the same. In this section, I argue that practices of discrimination against such indigenous minority language groups are driven by discourses of 'normalcy' and 'normalization' (practices used to oppress other marginalized and excluded groups of people) and I have borrowed these concepts specifically from disability theories (Davis, 2013 and Garland-Thomson, 1997). I am here using disability perspectives as a form of critical theory, akin, perhaps to queer theory; a lens through which to view multiple and complex practices and expressions of discrimination, conscious that systems and structures of power and oppression often operate by engaging in similar practices, approaches and narratives. Attempts have been made to articulate a critical theory that emerges out of disabled experience, most notably Robert McRuer's Crip Theory (2006). While this concept has been adopted by some in the academy, the notion of a 'crip theory' or even a 'crip identity' has not, as yet at least, been widely adopted in either academic or popular discourses on disability. So, for the purposes of this paper, I draw on discourses from what is here termed 'disability theories' as a lens through which to unpack practices and expressions of discrimination towards Welsh speakers.

Lennard Davis argues that the concept of disability can be understood as a social construction measured against concepts of the 'normate' and 'normalcy' so that, to understand 'disability', we first have to understand 'normalcy' (Davis, 2013, 1-14). Concepts of 'normalcy' are constructed in multiple and complex ways, but I outline three here to illustrate how discourses and practices of discrimination against Welsh speakers are informed by similar understandings of 'normalcy'. First, as Garland-Thomson argues, the 'normate' is 'the corporeal incarnation of culture's collective,

${ }^{3}$ Many searches on language as marker of identity and theology in Europe only throw up the works that Hannah Lewis (2007) and Wayne Morris (2008) have done with members of the Deaf Community in the UK. 
unmarked, normative characteristics' (Garland-Thomson, 2013, 340). That is, societies determine what is 'normal' by determining qualities and characteristics that are most important and valuable to that society. In the ancient world, for example, being physically fit and able to defend a state were valuable qualities, and being unable to do so was considered to be a deviation from 'normalcy' (Fontaine, 2007, 68). In Western societies today, in contrast, 'normalcy' is defined according to capacities to be economically productive. Characteristics that are valuable become normative for different societies and those who cannot participate in such 'normate' activities - who deviate from them - experience social marginalization. Second, 'normalcy' is determined according to qualities and characteristics that are more common or occur more frequently in a society. Davis shows how statistics gathering has been used for this purpose and illustrates this in relation to the way that IQ is commonly measured. Large numbers of people have their IQ assessed. From that large amount of data, an average IQ has been determined (which is labelled 'normal'). Once the average has been determined, then deviation from 'normalcy' can be established. A high IQ is considered to be a positive deviation, a low IQ a negative deviation (See Davis, 2013, 5). The more common something is the more normal it is likely to be considered to be. Third, I argue, concepts of 'normalcy' are also related to the maintenance of power. Those in positions of power construct discourses that affirm that how they live in and understand the world is 'normal'. All other worldviews are then measured against that of the 'normal' and subsequently deviancy can be determined. This serves those in power well because such a measure reinforces their position of power while affirming that deviance from their worldview is not 'normal' (Morris, 2014, 46). Vogt, for example, has indicated how maleness has historically been constructed as 'normal' in Christian discourses and that human value and worth has subsequently been measured against male normativity, thus marginalizing and oppressing women and reinforcing male dominance (Vogt, 2003, 49-61). All three approaches to the construction of normalcy can be seen at work in the ways that indigenous language groups other than English, in particular for our purposes here those who use Welsh, have been suppressed in the UK.

\section{Minority Language Groups as Deviants from Normalcy}

For nearly 150 years, educational policies in England and Wales have had a detrimental effect on indigenous languages other than English, especially Welsh and British Sign Language. For example, a nineteenth century policy of 'Welsh Not' was introduced in 'National Schools' in Wales that lasted into the early twentieth century. It was designed to stop children using Welsh in schools by making children wear either a knot, the letters WN, or the words 'Welsh Not' around their necks (Roberts, $1998,33)$ The aim, presumably, was to humiliate and to punish a child for speaking Welsh. Roberts explains that the technique was also used 'in Brittany, Gascony and Provence as punishment for speaking the local language' (Roberts, 1998, 33). She further notes how this operated in British colonies as a tool of empire as late as the 1950s in contexts such as Kenya. Here children would be made to wear 'a metal version with inscriptions such as 'I AM STUPID' or 'I AM A DONKEY' ... to punish children caught speaking Gikuyu at school or in its vicinity' (Roberts, 1998, 33). Similar attempts were made to stop Deaf children from using British Sign Language in favour of an 'oralist' ${ }^{4}$ approach to education implemented widely at the same period (Lane, 1984, 387). Deaf children, right into the middle of the twentieth century, would have their hands tied behind their backs, their hands hit with rulers or made to face the wall - which would have led to feelings of total isolation for people who communicate visually (Morris, 2008, 19-20). Such policies and practices of normalization to Englishness were justified as being in the best interests of the children. Welsh was thought not to have sufficient levels of sophistication to deal with legal or commercial complexities to the same degree as English (Roberts, 1998, 33). BSL was often referred to as a 'monkey language' suggesting that Deaf people were more akin to animals than human beings when they used BSL (Lewis, 2007,

4 'Oralism' is the term used to refer to an educational method among Deaf children that prohibits the use of sign language in order to make children learn to speak and lip-read the spoken language of the wider population (See Lane, 1984, 387). 
26). To speak Welsh or to use BSL or other minority languages would be to allow children to grow up disadvantaged, or so it was argued, to use languages that would 'hold them back' and prevent their intellectual development because, it was argued, their languages could not convey complex and sophisticated ideas to the same level as English (Roberts, 1998, 50). That, in turn, would mean a limited capacity to contribute to society in a 'normal' way.

What British society wanted was a monoglot English-speaking culture because the concept of 'Englishness' expressed in the English language was a valued quality in the British colonial agenda. If there was linguistic and cultural diversity within the British Isles, how could Britain impose Englishness as a marker of a civilised, 'normate' society in its' colonies? (Ladd, 2003, 79 and Roberts, 1998, 52) However, among the Welsh-speaking people who found refuge in Patagonia in the nineteenth century, as Lublin shows, all aspects of life including, home, church, business and government were managed perfectly well through the medium of Welsh. She further explains that Welsh Patagonians became one of the most successful 'mechanised rural communities... in the whole of South America' (Lublin, 2008, 10). Research has similarly shown that BSL is just as capable of conveying complex concepts and ideas on an equal basis with English (See discussion in Morris, 2008, 27-28). Indeed, favouring the teaching of English over BSL to Deaf children has often been the main cause of limited language acquisition and subsequently social and economic deprivation among Deaf people (Lane, 1984, 387). So Welsh (and BSL) was determined to be a deviation from 'normalcy' that needed to be 'rectified' because affirming and valuing diversity in language and identity did not serve the agendas of the more powerful English-speaking global colonisers.

The above example illustrates one of the historic arguments used against promoting, indeed actively discouraging, indigenous languages other than English. The legacies of these historic discourses still inform approaches to Welsh today. As a more contemporary example, the issue of economics is often used to justify conformation to linguistic normativity; economic expediency being a contemporary marker of something's value today. The production of bilingual road signs in Wales is often described by non-Welsh speakers as being unnecessarily expensive, as are bilingual utility bills, topics that create much controversy in phone-ins that discuss these topics on BBC Radio Wales. It is often argued that if everyone can speak English then why waste money producing things in Welsh too? Further, some local authorities in Wales, in majority English-speaking areas, recently complained about the requirements to comply with Welsh language rules set by the Welsh commissioner as 'too expensive' to implement (BBC, 2015 and Porter, 2015). However, economic expediency is too easily utilized as an argument in order to promote homogenized norms rather than diverse ways of living in and engaging with the world that reflects human difference. Pointing towards such economic concerns has served as a well-used argument to justify the will of 'normate' groups at the expense of the rights of those who deviate from 'normalcy', and not just in relation to linguistic minorities. How many times has this well-used rhetorical tool of economic expediency been put to use before to justify discriminatory practices? Familiar assertions might include, for example:

- Rules on maternity leave are too expensive for small businesses and will have a negative impact on the economy, used to justify discrimination against women in the workplace.

- Making buildings accessible to people with disabilities costs too much, they don't use our services anyway.

- Providing services in Welsh costs too much money and is not a priority in times of economic constraint.

While it is important to acknowledge that the economic resources of any society are always finite, arguments about economic expediency reflect societal priorities and concepts of 'normalcy'. It would be unthinkable to build a two-storey building without stairs so that able-bodied people who constitute a majority in society could not access the upper floor, but it can be considered an unnecessary expense to also add a lift to make it accessible to people with disabilities (a minority 
that deviates from 'normalcy'). The creation of a just and inclusive society that makes space for diverse peoples to live as equals requires investment that should be seen as essential, not an unnecessary or luxurious expense.

Here we see not only the argument that economic expediency is a highly valued principle in contemporary Western societies, the notion of normalization determined by frequency of occurrence is also at work here. The majority speak English, most Welsh people are fluent in English, so to make life easier for everyone everything should be in English, so the argument goes. This places no value or worth on to communities whose first language is Welsh and suggests no purpose in preserving and maintaining all that accompanies the use of Welsh as a language: Welsh culture, linguistic tradition, history, identity, literature, music and so forth. To take the position that something is only of value if it serves the interests of the majority would be an enormous backward step for most equality and human rights successes achieved in recent years and yet these very arguments are used against indigenous minority language groups in the UK. Why should we include you, why should money be invested in your language and culture, why don't you become like the English-speaking majority?

Welsh is sometimes credited as being one of the oldest language in Europe (Davies, 2014, 12-13). Whether or not this is true, it has a long literary and musical tradition and expresses particularly Welsh identities and ways of seeing the world that are very distinct from English. For many of the 550,000 or so people who live in Wales and speak Welsh, every time they are forced to use English, an historically (and relatively recently) imported language, the value of their history, culture and identity is diminished with the constant threat that all of it, one day, will disappear. In 1801, it was estimated that $70 \%$ of the population of Wales spoke only Welsh (Davies, 2014, 82), so the decline to somewhere about $20 \%$ being able to speak Welsh today has been rapid. In 1992, the United Nations adopted the Declaration on the Rights of Persons Belonging to National or Ethnic, Religious and Linguistic Minorities (Resolution 47/135). Article 2 states that people from linguistic minority groups: "have the right to enjoy their own culture, to profess and practise their own religion, and to use their own language, in private and in public, freely and without interference or any form of discrimination' (United Nations, 1992). In the twenty-first century in the United Kingdom, ethnic and religious identities are protected under the Equality Act of 2010 (See chapter one). While indigenous minority language groups are variously protected by legislation in some or all of the United Kingdom ${ }^{5}$, none of these laws provide the same level of rights and protection to minority language groups, indigenous or otherwise, as the Equality Act provides to other groups who experience social marginalization and discrimination. Notwithstanding the need for a transformation of societal attitudes around minority language groups, in a society where equality and human rights legislation reflects a societal will for human differences to be more valued and the rights of minorities better protected, the question of valuing and protecting the rights of linguistic minority groups is one yet to be fully addressed in the United Kingdom and across Europe today.

The rights and experiences of minority language groups in Europe has been given little attention in theological and religious discourses, although there is work on indigenous religions and spiritualities (for example, Harvey, 2002), theologies and indigenous peoples outside of Europe (for example, Tinker, 2008) and the indigenization of Western forms of Christianity in other parts of the world (for example, Engelke, 2007). The rights of many groups that experience discrimination and oppression of various kinds has also been an important theological agenda since the 1960s with the emergence

${ }^{5}$ For example, the Welsh Language Acts of 1967 and 1993, the Welsh Language (Wales) Measure of 2011 and the National Assembly for Wales (Official Language) Act 2012. Also measures such as the recognition of British Sign Language as a language of the United Kingdom in 2003. Other indigenous languages of the United Kingdom also receive an enhanced status and some protection under the European Framework Convention for the Protection of National Minorities. 
of Feminist, Black and Liberation Theologies. A plethora of diverse experiences now contribute to theological debate and identity, but hardly at all do the rights of indigenous minority language groups in Europe get any attention. Given the kinds of discrimination and oppression outlined above, informed by discourses of normalization that help us to understand that discrimination and oppression, the remainder of this paper begins to sketch, albeit briefly, the parameters of a Welsh language theology of liberation, that points towards the need for further examination, in light of liberationist discourses, of a theological response to the marginalized and oppressed status of minority language groups in Europe today.

\section{Christianity and the Welsh Language}

Why, especially in a context like Wales that has secularized rapidly over the past century (Morgan, 2011, 2), would a liberation theology be of use or significance in the struggle for the rights of Welsh speakers? Morgan notes that from the fifth century onwards, together with the emergence of the Welsh nation, Christianity has been a significant part of Welsh identity (Morgan 2011, 1). Indeed when the first Welsh settlers moved to Patagonia in 1865, the clear joint purpose was to be free to live through the medium of Welsh and to be free to practice their religion (Jones, 1998, 292-3). Religion and Welsh linguistic and cultural identity have thus been intertwined for centuries. Arthur Jones summed up this relationship well when he said that 'to the vast majority of Welsh people, losing the language would mean losing their religion as well' (quoted in Morgan, 2000, 371). Despite being increasingly secularized, therefore, religion and, specifically Christianity, it can be argued, is bound up with Welsh identity. Theology does, therefore, have a potential contribution to make to thinking about the status and future of the Welsh language.

It is of further significance that, with regard to Welsh and also BSL, the churches have often had a positive role to play in the survival and flourishing of these minority language groups. It was a religious figure in France, Charles Abbé de l'Epée who is often credited with pioneering the use of sign language as a means for education (Lane, 1984, 6), while the churches pioneered the establishment of Deaf Centres run by 'Missioners' that provided Deaf people with spaces where they could use sign languages freely at a time when educational policy was driven by oralism (Ladd, 2003, 125). Likewise in Wales, William Morgan's translation of the Bible into Welsh is often credited with formalizing Welsh in written form and has been widely regarded since as the standard of literary Welsh (Davis, 2014, 41). This Bible, together with the translation of liturgical resources into Welsh allowed the language to be used in Anglican churches, at least at the inception of Anglicanism when vernacular languages first started to be used (Davis, 2014, 39). When the Church of England (as it was in Wales until 1920) began to insist on the use of English in services, Non-conformist Christianity provided the principle spaces for Welsh language and culture to thrive right through to the twentieth century (Davis, 2014, 44-45).

Further, In 1916, Pope Benedict XV created the Archdiocese of Cardiff and, in so doing, argued that Wales as a 'nation of Celtic origin, differs so much from the rest of England in language, traditions, and ancient customs' which justified the creation of a separate episcopal structure from that of England (Morgan, 2000, 382). These were relatively pioneering sentiments for that period of history. Some Catholic bishops were also Welsh language supporters. Perhaps the most significant Welsh language activist of the twentieth century, Saunders Lewis, converted to Catholicism and was visited in prison in Wormwood Scrubs by the Bishop of Menevia, having been sentenced for setting fire to a military airbase in Penyberth on the Llŷn Peninsula (Morgan, 2000 383). Christian engagement with the struggle for the survival of the Welsh language and the rights of its users is also not new. In the 1960s and 1970s, Morgan notes, that leaders of the Cymdeithias yr laith Gymraeg (The Welsh Language Society), such as Dafydd Iwan and Ffred Ffrancis 'considered protest to be a form of Christian discipline' (Morgan, 2000, 391). The likes of Iwan were imprisoned in this period in their 
campaigns for what today seem like basic language rights, such as his campaigns for bilingual road signs (Morgan, 200, 393).

What has just been described is perhaps surprising given that Christianity and theology were widely employed by colonial powers like Britain to justify the suppression of language groups both in the UK and within its overseas colonies. Using English, and being members of the Church of England were viewed as markers of 'civilization' in much colonial propaganda (See the extract from the Missionary Register of 1812, for example, quoted in Sugirtharajah, 2001, 62). Further, for centuries, to be in the Welsh episcopal hierarchy in the Anglican Church, it was necessary to be English-speaking. As Morgan notes, in the Welsh 1662 Prayer Book, a service was included for the consecration of bishops but was never used until Timothy Rees was created bishop of Llandaf in 1931 (Morgan, 2000, 386), showing the predominance of English in what was for much of Anglican history in Wales a predominantly monoglot Welsh speaking country. As part of the Patagonia venture to find freedom of expression for Welsh speakers, it was often said that freedom was to be from the 'oppression of the established church' (Jones, 1998, 293).

So while Christianity has been hugely significant in sustaining the Welsh language throughout history, it has also been used as a tool to suppress Welsh. Emilie Townes argues that throughout history, religious traditions 'have driven people to incredible heights of valor and despicable degrees of cravenness' (Townes, 2009, 9). Townes is right and this is true of Christianity in particular. Christian discourses and the churches have been instrumental in justifying and promoting slavery, while that same faith tradition sustained and inspired many in slavery and their struggle for liberation. It continues to suppress and argue against gay rights while others within Christianity fight for liberation. Many church leaders remained silent in Nazi Germany, while others died in the fight against oppression. The list could go on but Townes' point, as I have shown, relates also to the linguistic minority groups who have faced suppression and marginalization by bigger more powerful language groups who set themselves up as normative. What I have sought to do in this paper so far, is to interrogate discriminatory practices towards Welsh speakers through the lens of theories of 'normalcy' and, in so doing, to show that indigenous linguistic minority groups should be understood as an oppressed minority identity group whose rights are not, as yet, protected fully in law. The task of beginning to find a way to transform such discriminatory practices is far larger than space in this paper allows. So, in conclusion, I begin to explore the contours of a Welsh language theology of liberation that builds on some of the positive contributions Christianity has made to sustaining the Welsh language historically, conscious that there is much more to develop than in what follows below.

\section{Towards a Welsh Language Liberation Theology}

Liberation theology, in its origins, was a theology concerned with soteriological questions and these were at the heart of the foundational texts of James Cone (1990) and Gustavo Gutierrez $(1988)^{6}$. According to Rivera-Pagan, liberation as a concept emerged in the 1960s amongst marginalized groups struggling against racism, poverty, repressive political regimes, patriarchy and homophobia (Rivera-Pagan, 2010, 2). By the early 1970s, the term had been coined by theologians similarly struggling against oppression (Rivera-Pagan, 2010, 2). Liberation is not, however, a new theological concept and its soteriological resonances go back to the Hebrew Bible. The story of the oppressed people of Israel in Egypt is paradigmatic for liberation theology (See Gutierrez, 1988, 90). God sees the struggle of people in living in oppression and grieves for their struggle. God acts to save, to transform their lives, not in the promise of some future eschatological hope, but of a better life in this world; a life free from oppression. God thus acts to save and liberates the people from Egypt. The characteristics of this process of liberation are: that God is always on the side of oppressed peoples; God's 'preferential option for the "poor"' (Rowland, 2007, 5) should be mirrored by the

${ }^{6}$ Original publication dates were Cone (1970) and Gutierrez (1971). 
church's solidarity with and alongside oppressed people's in their struggle for liberation (Boff \& Boff, 1998, 23); that the resources of non-theological discourses, be it Marxist economics, feminist theory or, as has been attempted here, disability theory, can and should be used to expose practices of oppression and help us to understand them better (Gutierrez, 1988, 123, 126); that liberation is a human possibility in this world and should be sought in this world (See Morris, 2014, 163); that a 'liberated state' is one in which human oppression and injustice is overcome and freedom and justice is realized (Morris, 2014, 163-4).

These characteristics begin, therefore can help to mark the contours of a Welsh language theology of liberation. It can begin with the understanding and commitment of the theologian that God is always on the side of oppressed people. This principle is one that has been affirmed repeatedly in liberation theologies and indeed, as I have argued elsewhere, it also means that God sides with people of other faiths and none if they are the objects of oppression by Christian persons (Morris, $2014,170)$. This principle is one to which I subscribe wholeheartedly and is at the centre of my personal, spiritual, theological and academic commitments. Subsequently, this paper calls on the churches to stand in solidarity with minority language groups in their struggle for survival and with peoples who fight daily for the human right to live their lives through their own language without discrimination. The first half of this paper was dedicated to beginning to understand the oppressed state of minority language groups by drawing on disability theories. I have only begun to do this work of exposing the oppressed state of indigenous minority language groups such as Welsh speakers. However, I am conscious that outside of theology, much of this work is also already underway (See, for example, Williams, 2008). Finally, the transformation of an oppressed state as a possibility that can be realized in this world is at the heart of the liberationist ideal. My proposal here is that there is place for a theological discourse that contributes to the liberation of marginalized minority language groups and, in particular, Welsh language users. If the marginalization of Welsh language users can be described as 'sinful' or, in liberationist terms, as a state from which people seek 'liberation', then the liberated state, a soteriological possibility for Welsh language users, is one in which their right to be free to use their language without discrimination should be understood as a real and achievable possibility.

\section{Conclusion}

In part, I write this paper with trepidation. I began by outlining the ways in which Welsh language users encounter the most extraordinary hostility on a daily basis and in writing such a paper I expose myself to that same kind of hostility. I guess it would not really be liberation theology without that risk, however. For some, this paper may appear to be anti-English too, an accusation often rallied against Welsh language activists. This paper is not meant to be anti-English any more than black theology is anti-white or feminist theology is anti-men. That is not the point. Rather, such theologies are orientated towards identifying the structures and systems of power that whiteness and maleness and Englishness represent that cause those who do not conform to white or male or English normativity to experience oppression. There is much work to be done to understand further the systems and structures used to marginalize indigenous minority language groups in Europe and this paper at least calls for further investigation into that and for contributions to be offered by those working in theology and religious studies. I further anticipate that I may be accused of overlooking the privileged status of Welsh in Wales and that often English-speakers feel oppressed there too. However, there are very few instances in which Welsh is in reality privileged over English and if it is, that is invariably necessary as a part of attempts to realize a more equal society. Elaine Graham's discussion of 'false parallelism', where historically powerful groups claim the discourses of minorities in order to argue that they are oppressed, is most informative here (Graham, 2013, 152$55)$. 
Emilie Townes argues that because of religion's power, it is 'imperative' for scholarship in theology and religious studies to 'be rigorous, relentless, and responsible to the issues of the day while pushing our understanding of what is before us in our modern/postmodern worlds' and that all scholarship 'should also help map out strategies for creating a more just and free society and world' (Townes, 2009, 4). While such a view would be contested by many parts of the academy, I concur with Townes. As I see it, as a practical and liberation theologian my task is to engage in an interrogation of practice and, where injustices and inequalities exist, to seek to transform it. The practices of discrimination with regard to minority indigenous language groups, such as those discussed above, have been given little attention in theology and religious studies more widely, and this lack of academic engagement is accompanied by a lack of engagement by Christian persons in the contemporary world to engage in the struggle of indigenous minority language groups. This paper aims to make a contribution to that lack of engagement and to encourage others to join in the task of thinking religiously and theologically about indigenous minority language groups.

\section{References}

BBC. $23^{\text {rd }}$ July 2015. Welsh Language Rules could cost some Councils $f 700,000$. Retrieved $29^{\text {th }}$ February 2016, from http://www.bbc.co.uk/news/uk-wales-33634802

Boff, L. and Boff, C. 1988. Introducing Liberation Theology. Tunbridge Wells: Burns \& Oates.

Cone, J. H. 1990. A Black Theology of Liberation: Twentieth Anniversary Edition. New York: Orbis Books.

Davies, J. 2014. The Welsh Language: A History. Cardiff: Gwasg Prifysgol Cymru.

Davis, L. J. 2013. "Introduction: Normality, Power, and Culture." In Davis, L. J. (ed.), The Disability Studies Reader. London: Routledge, pp.1-14.

Engelke, M. 2007. A Problem of Presence: Beyond Scripture in an African Church. Los Angeles: University of California Press.

Garland-Thomson, R. 1997. Extraordinary Bodies: Figuring Physical Disability in American Culture and Literature. New York: Columbia University Press.

Garland-Thomson, R. 2013. "Integrating Disability, Transforming Feminist Theory. "In Davis, L. J. (ed.), The Disability Studies Reader. London: Routledge, pp.333-53.

Graham, E. 2013. Between a Rock and a Hard Place: Public Theology in a Post-Secular Age. London: SCM Press.

Gutierrez, G. 1988. A Theology of Liberation: History, Politics and Salvation. London: SCM Press.

Harvey, G. (ed.), 2002. Readings in Indigenous Religions. London: Continuum.

Jones, R. O. 1998. "The Welsh Language in Patagonia" In Jenkins, G. H. (ed.) Language and Community in the Nineteenth Century. Caerdydd: Gwasg Prifysgol Cymru, pp.187-316.

Ladd, P. 2003. Understanding Deaf Culture: In Search of Deafhood. Clevedon: Multilingual Matters.

Lane, H. 1984. When the Mind Hears: A History of the Deaf. New York: Vintage Books.

Lewis, H. 2007. Deaf Liberation Theology. Aldershot: Ashgate.

Lublin, G. 2008. Memoirs and Identity in Welsh Patagonia: Constructions of Welsh Patagonian Identity as reflected in Memoirs written by Welsh descendants in the Province of Chubut towards the end of the Twentieth Century. Prifysgol Caerdydd: Unpublished PhD Thesis.

McRuer, R. 2006. Crip Theory: Cultural Signs of Queerness and Disability. New York: new York University Press.

Morgan, D. D. 2000. "The Welsh Language and Religion." In Jenkins, G. H. and Williams, M. A. (eds), The Welsh Language in the $20^{\text {th }}$ Century. Cardiff: Gwasg Prifysgol Cymru. Pp??

Morgan, D. D. 2011. The Span of the Cross: Christian Religion and Society in Wales 1914-2000. Cardiff: Gwasg Prifysgol Cymru.

Morris, W. 2008. Theology without Words: Theology in the Deaf Community. Aldershot: Ashgate.

Morris, W. 2014. Salvation as Praxis: A Practical Theology of Salvation for a Multi-Faith World. London: Bloomsbury T\&T Clark. 
Owens, N. $15^{\text {th }}$ October 2015. Tweets. Retrieved $25^{\text {th }}$ February, 2016, from https://mobile.twitter.com/lleoldotcymru/status/654728959909691392

Porter, G. 10 ${ }^{\text {th }}$ November, 2015. "'Welsh language less popular than Portuguese in Wrexham' council claims." In Daily Post. Retrieved $29^{\text {th }}$ February 2016, from http://www.dailypost.co.uk/news/northwales-news/welsh-language-less-popular-portuguese-10423999

Rivera-Pagan, L. N. 2010. "God the Liberator: Theology, History and Politics." In Valentin, B. (ed.), In Our Own Voices: Latino/a Renditions of Theology. Maryknoll: Orbis Books pp.1-20.

Roberts, G. T. 1998. The Language of the Blue Books: Wales and Colonial Prejudice. Cardiff: Gwasg Prifysgol Cymru.

Rowland, C. 2007. "Introduction: The Theology of Liberation." In Rowland, C. (ed.), The Cambridge Companion to Liberation Theology. Cambridge: Cambridge University Press, pp. 1-16.

Sugirtharajah, R. S. 2001. The Bible and the Third World: Precolonial, Colonial and Postcolonial Encounters. Cambridge: Cambridge University Press.

Tinker, G. E. 2008. American Indian Liberation: A Theology of Sovereignty. New York: Orbis Books Townes, E. 2009. "Walking on the Rim Bones of Nothingness: Scholarship and Activism. In Journal of the American Academy of Religion, 77(1). pp.1-15.

United Nations. 1992. Declaration on the Rights of Persons Belonging to National or Ethnic, Religious and Linguistic Minorities (Resolution 47/135). Retrieved 29 $9^{\text {th }}$ February 2016, from http://www.un.org/documents/ga/res/47/a47r135.htm

United Kingdom. 2010. Equality Act 2010. Retrieved $29^{\text {th }}$ February 2016, from http://www.legislation.gov.uk/ukpga/2010/15/contents

Vogt, K. 2003. "'Becoming Male': One Aspect of an Early Christian Anthropology." In Soskice, J. M. and Lipton, D. (eds), Feminism and Theology. Oxford: Oxcord University Press, pp. 49-61.

Williams, C. H. 2008. Linguistic Minorities in Democratic Context. Basingstoke: Palgrave MacMillan. 